\title{
CD2AP Gene
}

National Cancer Institute

\section{Source}

National Cancer Institute. CD2AP Gene. NCI Thesaurus. Code C97247.

This gene plays a role in both protein-protein interactions and cell division. 